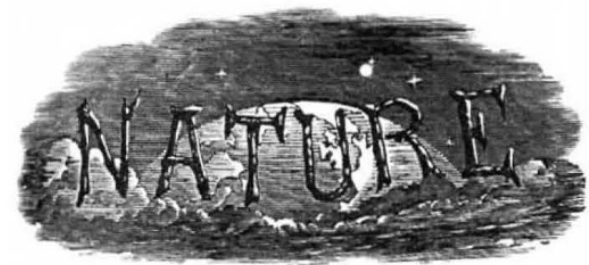

SATURDAY, JANUARY 26, 1924.

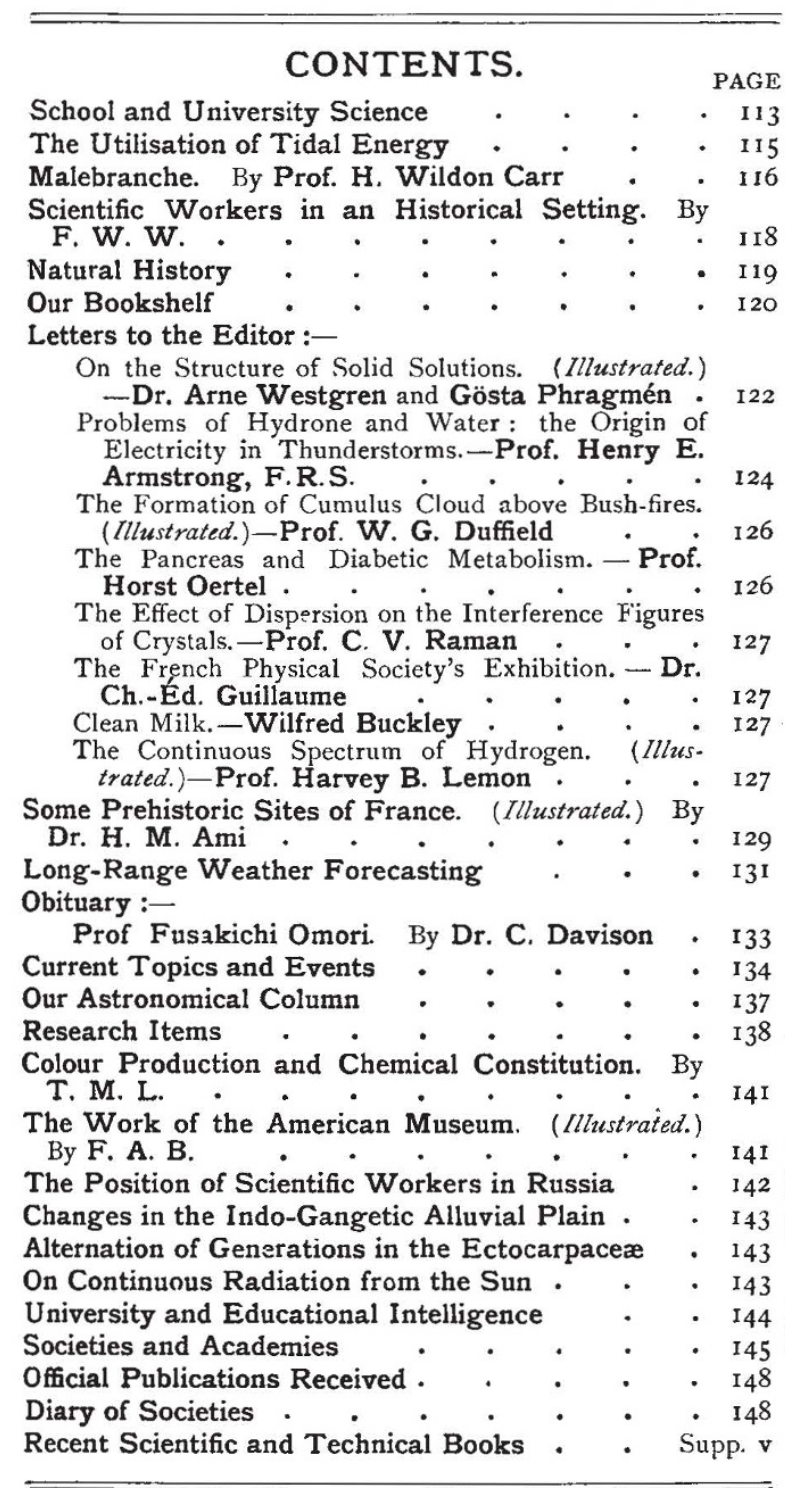

Editorial and Publishing Offices:

MACMILLAN \& CO., LTD.,

ST. MARTIN'S STREET, LONDON, W.C.2. Advertisements and business letters should be
addressed to the Publishers.

Editorial communications to the Editor.

Telegraphic Address: PHUSIS, LONDON.

Telephone Number: GERRARD 8830.

\section{School and University Science.}

GEVERAL weeks ago (December 22, p. 889), we referred to a pamphlet by Mr. John Galsworthy, in which it was pointed out that the world was more ready to use science and invention for destructive purposes than for social progress and " more hopeful of perfecting poison-gas than of abating coal-smoke or cancer." In his primitive instincts, man remains what he was thousands of years ago, and science has given him the strength of a giant without a corresponding development of his moral and ethical qualities. This view has often been expressed by men of science themselves, and Mr. Galsworthy's appeal to the civilised world to save itself from destruction is therefore welcome. It must not be forgotten, however, that while the might of science is generally recognised, its light is rarely perceived, and then often only as in a glass, darkly ; consequently, a great part of the thinking world is at heart afraid of science and its bewilderingly rapid advances. Yet it cannot be doubted that science has saved millions of lives in comparison with the thousands destroyed by it, and has, in addition, created unbounded riches and human comforts.

In his presidential address to the Science Masters' Association on January 3, Prof. A. Smithells placed some of his own War experiences beside Mr. Galsworthy's dicta. He was in charge of a school of life saving, dealing with three million men, drawn from all classes of society, and in circumstances in which a little real knowledge of elementary science might mean, and often did mean to them, the difference between life and death. "The rudiments of such knowledge," he said, "were not to be found in one man among a hundred." "I think we must reluctantly admit," he added, " that our science has edified and instructed far less than was reasonably to be expected from a movement that has been carried out for so long and with such vigour."

The advancement of science and the spread of scientific knowledge among the people are, broadly speaking, two distinct tasks. The first is pioneer work; the second missionary work. The university teacher is concerned mainly with the training of pioneers and preparation for professions; school teachers are, or should be, the great missionary force. Matter and method should be different in the two departments, since the aims are different.

The university teacher has to contend with great difficulties; he has to deal with a vast accumulation of facts and to cope with rapid advances. This leads him - perhaps compels him - to adopt a series of convenient formalities of procedure of a highly artificial kind. Subjects are segregated by an unnatural delimitation

NO. 283 O, VOL. II3] 
of frontiers, and dragged not only from their affiliations with history and the rest of human knowledge, but also from their association with life and the things of every day. This is pure or abstract science; it does not appeal to the multitude; many feel that it is too high and excellent for them - they cannot attain unto it.

It is not in any way derogatory to the university teacher to say that his work is not humanistic in the restricted sense in which this word is commonly used ; nay, rather, we should honour the man who takes the vow of poverty and leaves all to follow pure science. But text-books and manuals, as W. H. Hudson put it in "The Friendship of Books," and treatises designed by specialists for specialists do not properly come under the head of literature. "A book belongs to literature only when it transcends the interests of what we describe as our daily occupations and appeals to our common humanity. The physician will discover nothing to his purpose in a commentary on judicial procedure ; the lawyer will not seek his law in an essay on bridge-building; nor will the engineer be found working out the problems of stress and strain with a volume on typhoid fever at his elbow. . . . The physi cian, the lawyer, the engineer, alike have to meet, beyond the particular claims of their professions, the general claims of life at large." To prepare men in some way to meet the general claims of life at large is one of the main objects of school education.

There is, however, only one school for pioneers and missionaries alike. The school science teacher is trained in the university; he comes to his life's work at the zenith of his own powers, exulting in the conquest of the greatest heights of accumulated knowledge and eager to carry on research. But teachers, as Sir J. J. Thomson's Committee report on "Natural Science in Education " truly says, " tend to go on teaching as they themselves were taught." The young science master finds in the schools certain examinations-London matriculation, scholarship examinations and otherswhich are distinctly of the specialist type; he soon realises that successes in these examinations are held in high esteem, and he soon perceives that success is most surely attained by teaching what has been aptly described as "college science and water." A small percentage of pupils from the schools proceeds to the universities, and thus, in the end, the university teacher reaps his own sowing, as it were, once removed. Does he like it?

On this point, Prof. Smithells, in the address already cited, was very emphatic, speaking not only from his own experience, but also from that of others far removed from the stage of emeritus. "I have discovered," he said, "no relation between the mere quantity of chemical information a pupil brings from school and his subsequent progress in that science. I am tempted almost to say that I do not know even the type of the ratio. But I do know what it means to have pupils come with even a little well taught, and with an eager appetite for more." Besides the eager zest of the true naturalist, he asked only for literacy, an available knowledge of languages and a reasonable breadth of elementary science.

Thus, even in the case of the small percentage of pupils who proceed to the universities, the previous training in science does not satisfy those most concerned. But what about the rest, whose instruction in science ends with their schooling? The unpleasant truth is that the future needs of many are sacrificed to the immediate interests of the few; foundations are laid upon which nothing is afterwards built, and school science tends less and less to be taught in effective relation with life as it is and with things as they are in the great everyday world, and more and more as it is dealt with by professionals in seminaries.

Many disastrous mistakes have been made in educational policy, and it is not easy to say which has had the most detrimental effect. Among these particular errors, however, must be reckoned the forcing of university matriculation examinations on schools when it ought to have been the other way about (as it is beginning to be now, in part), namely, the acceptance by the universities of some reasonable examination based on a syllabus set up in the schools. To the university teacher, matriculation is often "merely" matriculation, a qualifying examination, a statutory examination which matters not at all, unless the candidate fails. It is not by any means certain that the most competent university teachers are put on the Matriculation Board ; indeed, it is not a great honour to be asked to serve on that body; the advice of schoolmasters is rarely sought; in fact, suggestions from schoolmasters are sometimes considered to be impertinent. Yet matriculation examinations have to be taken seriously in the schools, and they have acquired considerable academic value in the minds of business men.

Though university teachers are sometimes appalled at the results of what is, after all, a weak reflection of their own teaching, yet they still persist in shaping the school science course by means of their examination schedules. They are often very conservative, and few of them have given active support to a movement which originated in the schools and is mainly directed towards broadening the basis of school science and getting specialist science entirely out of the school certificate stage of a boy's education.

This general science movement was, in part, a protest No. 283 O, vOL. I I 3 ] 
by science masters against the assumption that they stand outside the body of teachers engaged in what is called general education, and are mainly charged with the duty of preparing a few boys for later professional study. A few years ago, the General Medical Council endeavoured to make elementary science part of the professional education of medical students and to take it out of the hands of schoolmasters altogether. In this the Council was supported by some science teachers in the newer universities. Thus, in the Times Educational Supplement can be read the following: "With regard to the biological sciences, our opinion is that they cannot be studied with real advantage by the average boy till he is at least 17 or 18 years of age. Further, that 'Elementary Biology,' as embodied in the practical course laid down by Prof. Huxley, will not serve as a sufficient foundation for a high class medical course for the present or immediate future." The date of this is I III ; its effect on the teaching of biology in schools has been disastrous; so much so that, even now, many otherwise enlightened governing bodies cannot be induced to make provision for the teaching of biology because they are convinced that this is part of the professional training of the medical man.

The difficulties are great, but are not insurmountable. The entire abolition of university matriculation examinations from schools would lead to greater freedom; the broadening of the basis of scholarship examinations and a corresponding reduction of the standard required in separate subjects would discourage too early specialisation; and finally, a vigorous campaign on the part of biologists might get rid of the unfortunate misconception about that subject that exists at present. These things together would render possible the introduction into schools of a reasonable course of general science framed on humanistic lines-

" an unerring knowledge of the things that are, To know the constitution of the world and the operation of the elements ;

The beginning and end and middle of times,

The alternations of the solstices and the changes of seasons,

The circuits of years and the position of stars ;

The nature of living creatures and the raging of wild beasts,

The violences of winds and the thoughts of men, The diversities of plants and the virtues of roots." 1

"When school science has this outlook," as was recently said, "it will lie closer to the human heart than it does at present, and a common bond of sympathy will be formed between all who are guiding the growth of young minds for both beauty and strength."

1 Book of Wisdom, vii. 16-20. No. 283 O, vol. I I 3 ]

\section{The Utilisation of Tidal Energy.}

Studies in Tidal Power. By Norman Davey. Pp. xiii +255 . (London, Bombay and Sydney: Constable and Co., Ltd., I923.) 32s. net.

T THILE the development of tidal power has $\sqrt{ }$ attracted inventors for many years, no tidal power scheme of any appreciable size has hitherto been constructed. The last few years have, however, shown a greatly increased interest in the subject, and both in Great Britain and in France specific schemes for large-scale developments have been under consideration by governmental committees.

Schemes involving the use of the Severn estuary have been considered in some detail by the Board of Trade Water Power Resources Committee, the third interim report of which, issued in 1920 , dealt exclusively with the question of tidal power. The Committee, as a result of its investigations, came to the conclusion that, while the technical information available was not sufficiently precise to enable it to express a final opinion as to the feasibility of the schemes submitted to it, there was a strong prima facie case for the more detailed examination of the problem. In view of its importance and of the possibilities attaching to its successful solution, the Committee urged that a special Tidal Power Commission composed of technical and scientific members should be appointed to undertake the necessary investigation. About the same time a Severn scheme was put forward in the public Press by the Engineering Department of the Ministry of Transport, and it is possible that the opposition offered to this by an important section of the daily Press was in part responsible for no further steps being taken in the matter of the Committee's proposal.

In France the Senate has now voted a Bill, already passed by the Chamber, providing funds for the construction of a tidal power station of experimental type at Aber-vrach near Brest. The proposed barrage will be 150 metres long and the turbines will have a maximum output of about r 200 h.p. The tidal station is to be worked in conjunction with a second hydroelectric station utilising the waters of the river Diouris, which discharges into the estuary of Aber-vrach. This will be used to supplement and regularise the output of the tidal station. It is estimated that the two stations will give a constant minimum output of 1600 h.p. and a maximum of 3200 h.p. The annual output is estimated at about II million B.O.T. units. The construction of this scheme should throw valuable light on many of the problems outstanding in connexion with the operation of such installations.

The work under review is one of the first books in English to deal exclusively with the important subject 